\title{
Immune suppression by neutrophils and granulocytic myeloid-derived suppressor cells: similarities and differences
}

\author{
Janesh Pillay • Tamar Tak • \\ Vera M. Kamp • Leo Koenderman
}

Received: 17 September 2012 / Revised: 14 January 2013 / Accepted: 30 January 2013 / Published online: 20 February 2013

(C) The Author(s) 2013. This article is published with open access at Springerlink.com

\begin{abstract}
Neutrophils are essential effector cells in the host defense against invading pathogens. Recently, novel neutrophil functions have emerged in addition to their classical anti-microbial role. One of these functions is the suppression of $\mathrm{T}$ cell responses. In this respect, neutrophils share similarities with granulocytic myeloid-derived suppressor cells (G-MDSCs). In this review, we will discuss the similarities and differences between neutrophils and G-MDSCs. Various types of G-MDSCs have been described, ranging from immature to mature cells shaping the immune response by different immune suppressive mechanisms. However, all types of G-MDSCs share distinct features of neutrophils, such as surface markers and morphology. We propose that G-MDSCs are heterogeneous and represent novel phenotypes of neutrophils, capable of suppressing the immune response. In this review, we will attempt to clarify the differences and similarities between neutrophils and G-MDSCs and attempt to facilitate further research.
\end{abstract}

Keywords Myeloid-derived suppressor cells · Neutrophil · Inflammation · Immune regulation • T-cell suppression

J. Pillay $\cdot$ T. Tak $\cdot$ V. M. Kamp $\cdot$ L. Koenderman $(\bowtie)$ Department of Respiratory Medicine, University Medical Center Utrecht, HP. E 03.511, Heidelberglaan 100, 3584 CX Utrecht, The Netherlands e-mail: 1.koenderman@umcutrecht.nl

\section{J. Pillay}

Department of Anesthesiology, University Medical Center Utrecht, Heidelberglaan 100, 3584 CX Utrecht, The Netherlands

\section{Introduction}

Neutrophils are important effector cells in the innate immune response against invading micro-organisms [1]. The cells possess multiple powerful mechanisms enabling them to migrate towards, engage with, in particular, small targets and kill them intracellularly [1]. The importance of these cells is illustrated by the fact that neutrophils and/or neutrophil-like cells have already developed early in evolution [2]. Cells with phagocytic function and neutrophil-specific proteins are now found in species ranging from simple organisms such as sea fan corrals [3] to complex organisms such as mammals [4].

The evolution from simple to complex organisms resulted in the origin of the adaptive immune system. This review will focus on recent data showing the existence of multiple functional phenotypes of neutrophils that, beyond their well-recognized anti-microbial functions, are able to steer and shape the adaptive immune system. But before reviewing these functional phenotypes in detail, it is important to first discuss recent data with respect to: (1) definitions for priming and phenotypes and (2) the life cycle and compartmentalization of neutrophils.

Switching phenotype and priming: two distinct mechanisms

In this review, we define granulocytic myeloid-derived suppressor cells (G-MDSCs) as a phenotype of neutrophils. A phenotype refers to a cell that either in the bone marrow or by instruction in the periphery (Fig. 1) develops towards a cell with a specialized function, which distinguishes it from other cells. In the case of G-MDSCs, this would be their ability to suppress the adaptive immune response. It is only recently that neutrophils are accepted to have multiple 


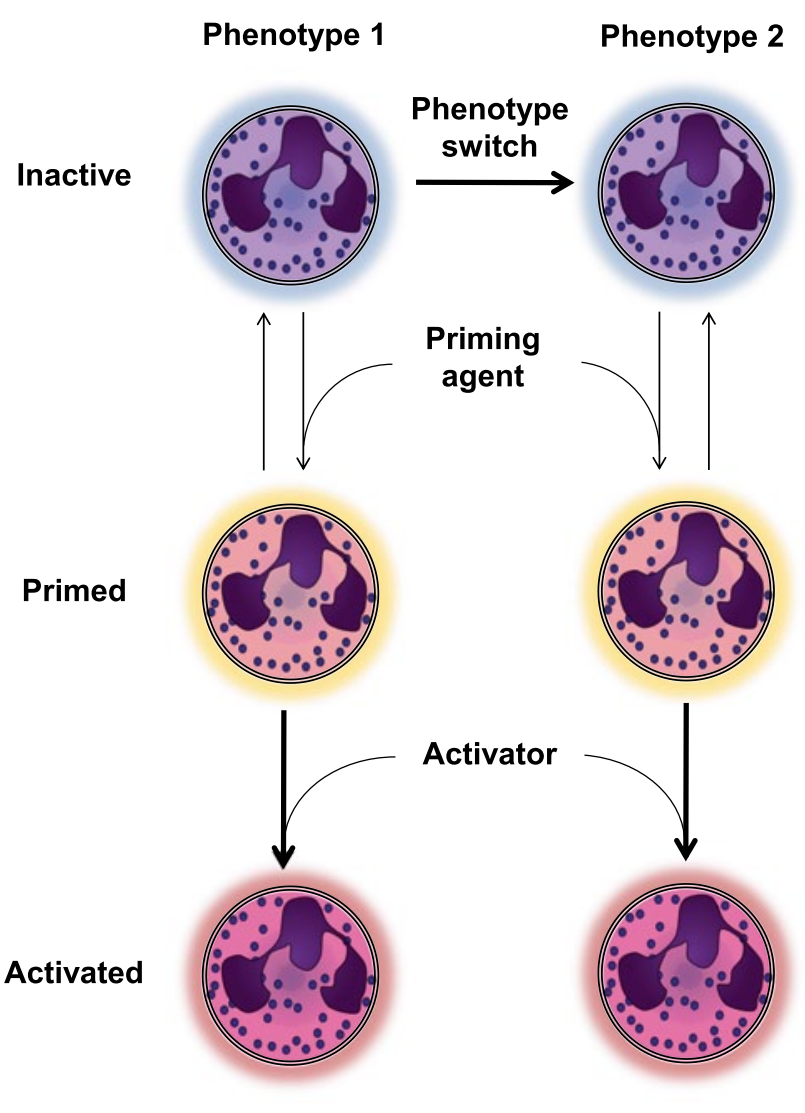

Fig. 1 Priming versus functional phenotypes of neutrophils. This figure illustrates that phenotypes are defined as cells that retain specialized functions for a prolonged time. Priming refers to the mechanism that is rapidly and reversibly induced by soluble or cell associated mediators such as platelet activating factor (PAF) [7], which potentiate functions of neutrophils but do not change their overall function. Priming can potentiate all different phenotypes and functions, such as migration, production of ROS and phagocytosis

phenotypes and, surprisingly, little is known regarding the occurrence and induction mechanisms of these neutrophil phenotypes. Few examples exist of neutrophils switching between phenotypes and it is unknown whether neutrophils with different phenotypes differentiate from specialized precursors (see also below, e.g., Fig. 4). Phenotype switching by neutrophils has recently been reported by the addition of granulocyte macrophage colony-stimulating factor (GM$\mathrm{CSF}$ ) to mature and immature murine bone marrow-derived neutrophils. These neutrophils acquired properties of dendritic cells such as antigen presentation but retained their anti-microbial properties [5].

In contrast to induction of phenotypes, priming can also modulate the functionality of neutrophils. Non-primed neutrophils are relatively refractory to activation, limiting aspecific activation. This process functions as a safe lock mechanism and has been extensively reviewed elsewhere [6, 7]. Only after priming (typically by a cytokine, chemokine or bioactive lipid) can a neutrophil optimally exert functions such as the generation of a respiratory burst induced by fMLF [8] or chemotaxis [9].

Priming is a mechanism distinct from changing of phenotype, as it reversibly potentiates effector functions of neutrophils but does not change their overall function.

The life cycle of a neutrophil

Despite the consensus regarding the importance of neutrophils in host defense. surprisingly little is known about very basic characteristics of these cells in respect to their life cycle. As stated above, it is only recently that neutrophils are accepted to have multiple phenotypes. A possible reason that neutrophil subtypes were overlooked is the view that they are short-lived cells, which perform their duty and subsequently rapidly go into apoptosis in the tissue. This view is based on experiments labeling and tracing neutrophils with radioactive isotopes [10-13]. These experiments, which used ex vivo and potentially toxic labeling techniques, showed a peripheral blood half-life of only 7-25 h. Our recent paper using in vivo labeling with the stable isotope ${ }^{2} \mathrm{H}$ suggests a half-life of 3.8 days [14]. This result remains a matter of debate, as Li et al. [15] suggested that the observed results could also be explained by a 3.8-day division time of neutrophil progenitors. Moreover, the view that neutrophils in tissue cannot return to the peripheral blood has been challenged by several studies. Already in 1974, Vincent et al. [16] showed in calves that, after disappearance of most labeled neutrophils from blood, hydrocortisone can induce their return into the circulation, where they stay for at least another $24 \mathrm{~h}$. More recently, several studies have provided additional evidence that support the view that neutrophils do not simply die by apoptosis in the tissues but move to additional sites in the body. These studies show homing of neutrophils to secondary lymphoid tissue [17] and reverse migration of cells over endothelium in vitro and in vivo [18, 19]. Reverse migration and remobilization of neutrophils has also been shown very elegantly in zebrafish larvae demonstrating migration of neutrophils from a site of inflammation toward different organs throughout the organism [20].

Taken together, these data demonstrate that at least a subpopulation of neutrophils can survive for much longer than previously appreciated, allowing more time for these cells to switch phenotypes and exert functions beyond cytotoxicity against invading pathogens.

\section{Myeloid-derived suppressor cells}

One of the recently described neutrophil phenotypes is the myeloid-derived suppressor cells (MDSCs). These cells were firstly identified at the beginning of this century and 
described as immature myeloid cells that suppress immune responses in the spleens of tumor-bearing mice [21-23]. Such immune suppression was earlier attributed to myeloid cells, but this activity was confined to differentiated cells such as macrophages [24]. As research progressed on these immature myeloid cells, it became clear that they consisted of a heterogeneous group of cells, consisting of (precursors of) granulocytes and monocytes, and that these cells were not always immature [25]. The term myeloid-derived suppressor cell was coined in 2007 by Gabrilovic et al. [26] to encompass the heterogeneity of these cells.

Considering the granulocytic component of MDSCs, there is still discussion on their differences and similarities with neutrophils. Recently, research on neutrophils described various novel neutrophil functions, such as antigen presentation, inhibition of immune responses, and induction of B cell class switching [27-29]. In addition, it has been known for decades that neutrophils reside in the spleen in health and disease [30], a location frequently sampled for MDSCs [31-33]. As the research fields concerning neutrophils and granulocytic MDSCs seem to have evolved in separate ways, this review will attempt to clarify the differences and similarities between these cells and attempt to unify and guide further research.

\section{Identification of neutrophils and G-MDSCs}

G-MDSCs are MDSCs of granulocytic origin. According to this definition, these cells can belong to one of three different types of granulocytes: neutrophils, eosinophils, and basophils. However, only neutrophils have been described as a component of MDSCs [34, 35]. Multiple surface markers and characteristics that identify G-MDSCs have been described. Before going into detail about the different G-MDSCs characteristics, we will first clearly define how to identify a neutrophil in order to discuss the similarities and differences with G-MDSCs.

\section{Neutrophil identification}

The gold standard to identify a neutrophil is by visual inspection under a light microscope. When stained with May-Grünwald-Giemsa or similar, neutrophils can be easily distinguished by the shape of their nucleus and cytoplasmic color/granularity (Fig. 2). The nucleus should either have a band or (hyper)segmented shape and a light pink/purple cytoplasm filled with similarly colored ("neutrophilic") granules [36].

Identification of neutrophils by flow cytometry may be more convenient than visual inspection, as the latter is a more laborious and subjective method. In mice, flow cytometric identification of neutrophils can easily be performed by using the neutrophil-specific marker Ly6G [37]. Traditionally, Ly6G is combined with CD11b, but this is not necessary when using the specific Ly6G antibody 1A8 [37].

Human neutrophils lack a marker similar to Ly6G, but can be reliably identified nonetheless (Table 1). In studies on MDSCs, CD11b and CD33 are traditionally used as markers for human MDSCs. However, these markers are expressed on all cells of the myelocytic lineage and on NKcells, so they are not specific enough to identify human neutrophils [38-40]. Other markers used are CD14 and CD15. Neutrophils (or G-MDSCs) are found to be $\mathrm{CD} 14^{\text {neg/low }}$ and $\mathrm{CD} 15^{\text {pos }}$, whereas monocytes (or Mo-MDSCs) are CD14 ${ }^{\text {high }}$ and $\mathrm{CD} 15^{\text {neg/low }}$ [35]. Unfortunately, these two markers are not sufficient to identify neutrophils, as eosinophils have a similar CD15 expression [41]. We suggest CD16 as an additional marker, as mature neutrophils are $\mathrm{CD} 16^{\text {high }}$, eosinophils are $\mathrm{CD} 16^{\text {neg }}$, and monocytes either $\mathrm{CD} 16^{\text {neg }}$ or CD16 $6^{\text {int }}$. Therefore, CD16 allows for distinction between these two types of granulocytes. An additional advantage of using CD16 is that its expression varies between the different stages of neutrophil maturation: neutrophil progenitors capable of dividing are CD16 ${ }^{\text {neg }}$, with increasing expressions in metamyelocytes, banded and mature neutrophils, respectively [38]. CD16 alone is not enough to identify neutrophils, since NK cells and monocytes also express this marker [42].

In short, we suggest the use of Ly6G for identification of murine neutrophils and the combination of CD14, CD15 and CD16 for identification of human mature neutrophils. We do want to emphasize the importance of visual inspection, which remains the gold standard to identify neutrophils. Visual inspection should routinely be performed in order to eliminate the possibility of other cell types expressing neutrophil markers under certain clinical conditions.

\section{G-MDSCs versus neutrophils}

As mentioned above, G-MDSCs have been implicated to have a similar expression of CD14 and CD15 as neutrophils, while mature or banded G-MDSCs and neutrophils also have similar CD16 expression. However, there seems to be one prime feature that distinguishes them from normal neutrophils: immune suppression. Several methods have been proposed to distinguish between the suppressive G-MDSCs and circulating neutrophils and will be discussed below.

Identification of G-MDSCs: flow cytometry

Several papers have shown differences between G-MDSCs and normal neutrophils in the expression of cell surface markers visualized by flow cytometry. Greifenberg et al. [43] identified two subsets of neutrophils with a different $\mathrm{CD} 11 \mathrm{~b}$ expression in the spleens of healthy mice. Of these 


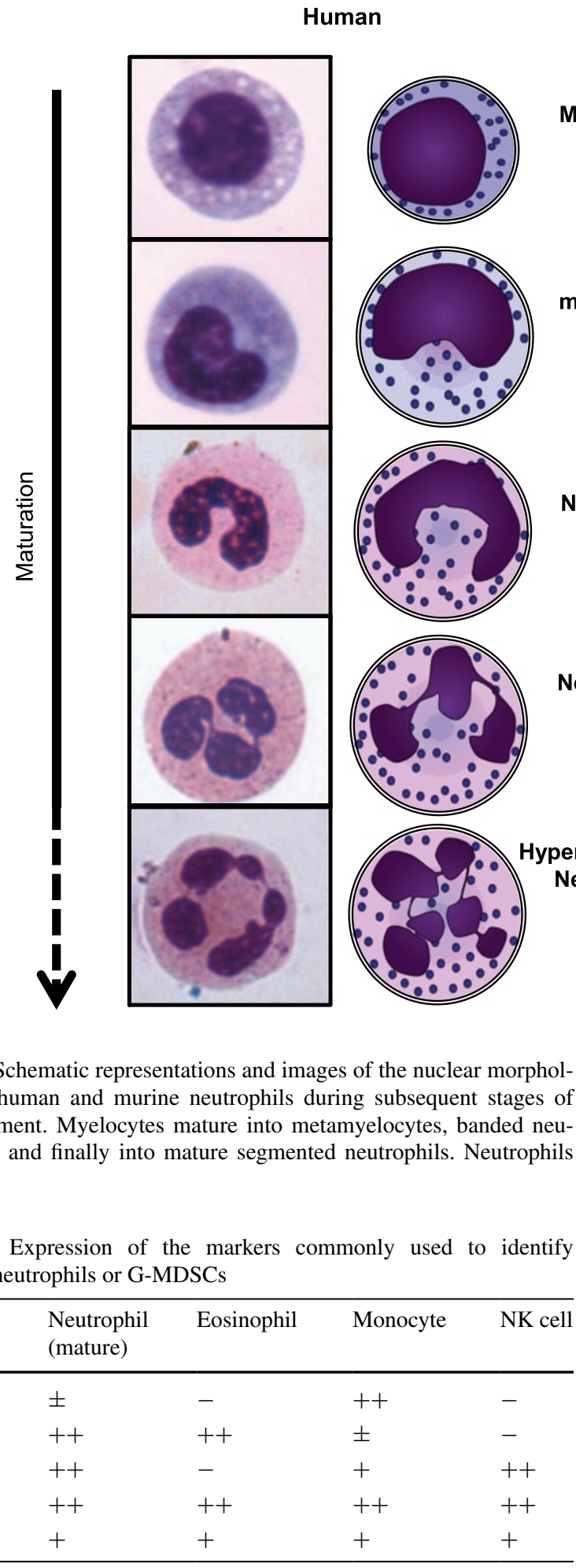

Fig. 2 Schematic representations and images of the nuclear morphology of human and murine neutrophils during subsequent stages of development. Myelocytes mature into metamyelocytes, banded neutrophils, and finally into mature segmented neutrophils. Neutrophils

Table 1 Expression of the markers commonly used to identify human neutrophils or G-MDSCs

\begin{tabular}{lllll}
\hline & $\begin{array}{l}\text { Neutrophil } \\
\text { (mature) }\end{array}$ & Eosinophil & Monocyte & NK cell \\
\hline CD14 & + & - & ++ & - \\
CD15 & ++ & ++ & \pm & - \\
CD16 & ++ & - & + & ++ \\
CD11b & ++ & ++ & ++ & ++ \\
CD33 & + & + & + & + \\
\hline
\end{tabular}

two populations, only the relatively low (but still positive) CD11b-expressing cells were found to be immune suppressive and, therefore, exhibited characteristics of G-MDSCs. Youn et al. [44] found an increased proportion of neutrophils expressing SLAMF4 (CD244) in mice bearing
Murine

Myelocyte

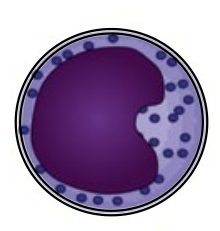

Metamyelocyte

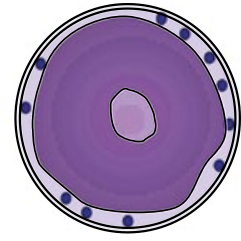

Banded

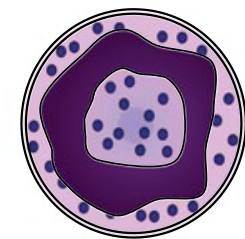

Mature Neutrophil
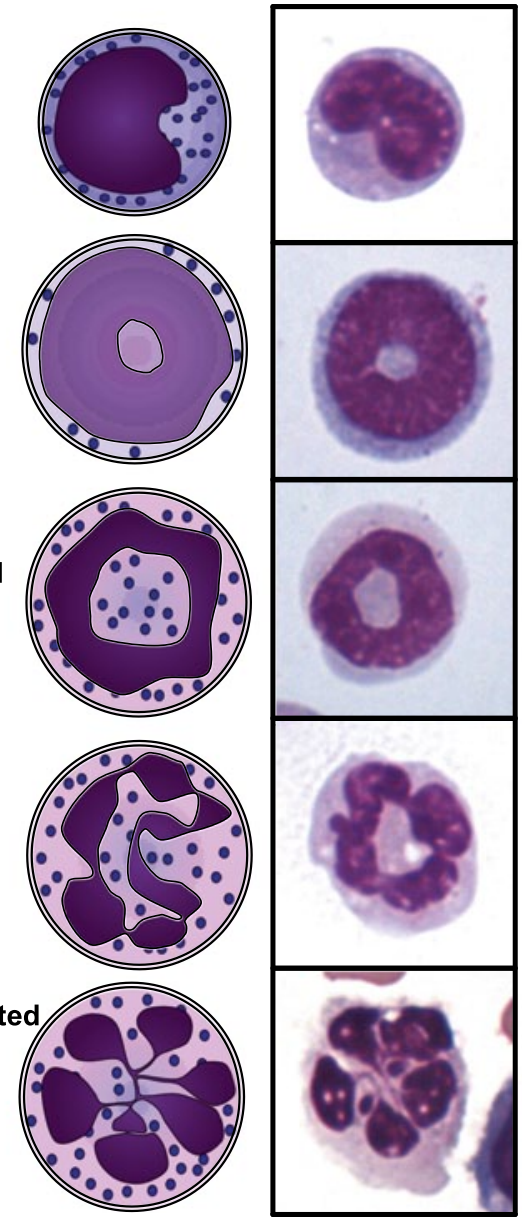

may also become hypersegmented, with more than 4 nuclear lobes (human) or a cloverleaf shape (mouse). It is unknown whether hypersegmented neutrophils are more mature than segmented neutrophils

several different tumors. In some, but not all, of these tumor models, there was also an increased population of neutrophils expressing CSF1-R (CD115). When they compared the CD244-positive and -negative populations, only the CD244 ${ }^{\text {pos }}$ cells were found to be immune suppressive. The consequences of these findings for the human situation remain to be established.

In humans, an enhanced expression of the IL-4R $\alpha$ (CD124) was found on suppressive cells. This marker was found on the G-MDSCs of patients with non-small cell lung carcinoma [45]. However, another paper found CD124 expression to correlate only with immune suppression by monocyte-derived MDSCs [46]. Therefore, it remains uncertain whether CD124 can be used to identify human G-MDSCs.

In severely injured patients and in a human acute inflammation model, our group has identified distinct 


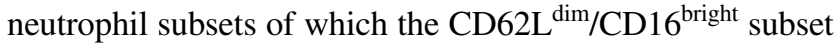
was immune suppressive [29]. In contrast to the findings by Greifenberg, who showed G-MDSCs to be lower in CD11b expression, this CD62L ${ }^{\text {dim}} / \mathrm{CD} 16^{\text {bright }}$ subset showed a trend of higher $\mathrm{CD} 11 \mathrm{~b}$ expression [43]. Other markers upregulated in these suppressive cells were CD11c, CD32, CD35, CD45, and CD66b. The suppressive cells could, however, not be clearly distinguished on the basis of these latter markers.

Puga et al. [28] show two different subtypes of neutrophils in the human spleen, named $\mathrm{N}_{\mathrm{BH} 1}$ and $\mathrm{N}_{\mathrm{BH} 2}$ (B cell helper neutrophils). These subtypes have a higher expression of B cell activating factor (BAFF) and CD11b, and lower expressions of CD15, CD16, CD62P, and CD62L compared to blood cells. Additionally, the $\mathrm{N}_{\mathrm{BH} 2}$ cells have a higher CD27, CD40L, CD86, and HLA-II compared to both circulating and $\mathrm{N}_{\mathrm{BH} 1}$ neutrophils. Unfortunately, they only assessed immune suppression by splenic neutrophils as a whole. Therefore, it is unclear whether only one of these two subtypes or both are suppressive and which markers can distinguish between suppressive and normal neutrophils.

In conclusion, many markers are shown to distinguish suppressive G-MDSCs from non-suppressive neutrophils. However, so far, none of these candidates have been confirmed by other papers and some findings are contradictory (e.g., CD11b, IL-4R $\alpha$ ). Thus, to date, no single or combined expression of surface markers can reliably identify suppressive neutrophils or G-MDSCs in either humans or mice.

\section{Identification of G-MDSCs: density centrifugation}

Centrifugation of blood over a layer with a density of $1.077 \mathrm{~g} / \mathrm{ml}$ is a common step in the isolation of leukocytes from whole blood [47]. Due to their relatively high density, neutrophils end up below the layer, on top of the erythrocyte fraction, whereas the PBMC fraction is found in the interphase between this layer and the plasma. Schmielau and Finn [48], and Rodriquez et al. [49] found immune suppressive G-MDSCs in the PBMC fraction of cancer patients. These cells show an activated phenotype, characterized by increased CD66b and CD11b expression. Also, they show the immune suppression to be mediated by the CD66bexpressing cells [49]. However, they did not show whether the neutrophils with normal density in the same patients were also suppressive, and therefore it remains uncertain whether density centrifugation can distinguish between suppressive and non-suppressive cells. In vitro activation of neutrophils from healthy donors resulted in neutrophils with a similar density and suppressive capabilities, indicating that, in this system, G-MDSCs might be activated neutrophils [49]. Density centrifugation remains a widely used method for the isolation of human MDSCs in cancer patients, but there is still a lack of data on the differences between these G-MDSCs and neutrophils from these patients [50].
Identification of G-MDSCs: gene profiling

Even though it is not possible to isolate cells based on gene expression patterns, it is likely that cells with different functions will have different gene expression profiles. Fridlender et al. [51] showed differences in the transcriptome of naïve bone marrow neutrophils in healthy mice, blood G-MDSCs from tumor-bearing mice, and tumor-associated neutrophils (TANs). The cells from the blood of tumor-bearing mice have a low expression of mRNA for cytokines and chemokines compared to TANs. Compared to bone marrow cells, G-MDSCs show a low mRNA expression of granule proteins, NADPH complex subunits, and peroxidases. Unfortunately, the location of neutrophils can influence their functionality [52], so it is unclear whether these differences were specific for G-MDSCs or a result of different localization/maturation. For instance, it is likely that neutrophils produce their granule and respiratory burst proteins during maturation and store them for later use, explaining the high amounts of mRNA for these proteins [53, 54].

Another transcriptome analysis by Youn et al. [44] compared neutrophils from naïve and tumor-bearing mice. It showed an upregulation of MPO and proteins involved in cell-cycle pathways in G-MDSCs from tumor-bearing mice. In contrast, neutrophils from naïve mice show an upregulation in mRNA for cytokines, chemokines, proteases, and other pro-inflammatory proteins.

Other proteins found to be upregulated in G-MDSCs are arginase-I [49, 51, 55, 56], iNOS [57], and IL-10 [55]. As these three proteins are directly involved in mechanisms of immune suppression by G-MDSCs, they will be described in more detail in the section below.

\section{Identification of G-MDSCs: nuclear morphology}

MDSCs are in general described as young or immature cells [58]. The nuclear morphology of neutrophils provides a simple tool to assess their age. Neutrophils possess a distinct nuclear morphology in different stages of development (Fig. 2). Early progenitors have a round nucleus, which changes during maturation into the horseshoe, or "banded", shape of a human immature neutrophil (a ringshape in mice). When these cells fully mature, the nucleus starts showing indentations and is called segmented. When the nucleus has 4 or more segments in humans, or a cloverleaf-shape in mice, it is called hypersegmented. Since neutrophils gain more indentations and segments upon maturation, it is tempting to address hypersegmented cells as "old". However, there is evidence that segmented and hypersegmented neutrophils in humans are of similar age [59].

In the paper of Greifenberg et al. [43] mentioned above, the G-MDSCs population had a clear ring-shaped morphology, whereas the cells with a segmented nucleus were not 
suppressive. This supports the notion of G-MDSCs being young/immature cells. Also, Fridlender et al. showed in a tumor model that immune suppressive TANs are mostly immature, whereas, after TGF- $\beta$ inhibition, the TANs were found to be hypersegmented and did not suppress tumor growth, thus implying loss of immune suppression [37].

Other papers, however, shave shown no difference in nuclear morphology for the suppressive cells [44, 60]. Similarly, Dumitru et al. [35] have extensively reviewed the phenotype of suppressive G-MDSCs in human cancers and found them to be segmented in 8 out of 9 papers where the nuclear morphology was assessed [45, 48, 49, 56, 61-64]. In addition, in our model of acute inflammation and in severely injured patients, we have shown only the hypersegmented cells to be immune suppressive [29].

Taken together, nuclear morphology is not a good indication for immune suppressive functions and, therefore, of G-MDSCs. However, these differences do indicate the existence of several distinct G-MDSCs subtypes.

\section{G-MDSCs identification and subtypes: conclusion}

When studying potential G-MDSCs (or suppressive neutrophils), one should first ascertain the cells of interest to be neutrophils. This can be done by flow cytometric determination of CD14, CD15, and CD16 expression and, ideally, assessing nuclear morphology after cell sorting. Density centrifugation is not a suitable method for isolating suppressive neutrophils, as it cannot distinguish suppressive cells from non-suppressive activated cells.

In various studies, different surface markers are shown to distinguish G-MDSCs or suppressive neutrophils from their non-suppressive counterparts. However, there are differences in expression of (activation) markers and nuclear morphology between these suppressive subsets. This demonstrates that there are several G-MDSCs phenotypes, possibly reflecting differences in localization, clinical condition, or origin.

\section{Mechanisms of immune suppression by suppressive neutrophils and G-MDSCs and their relevance to disease}

Proliferation of T cells is influenced by many environmental factors. These factors, such as cytokines, growth factors, and amino acids, are easily altered in an inflammatory environment in the presence of other inflammatory cells such as neutrophils and G-MDSCs. Suppression of T cell responses can be achieved by depletion of essential amino acids from the microenvironment, such as L-arginine [65], (massive) generation of reactive oxygen species [48], or through cellcell contact (Fig. 3) [29].

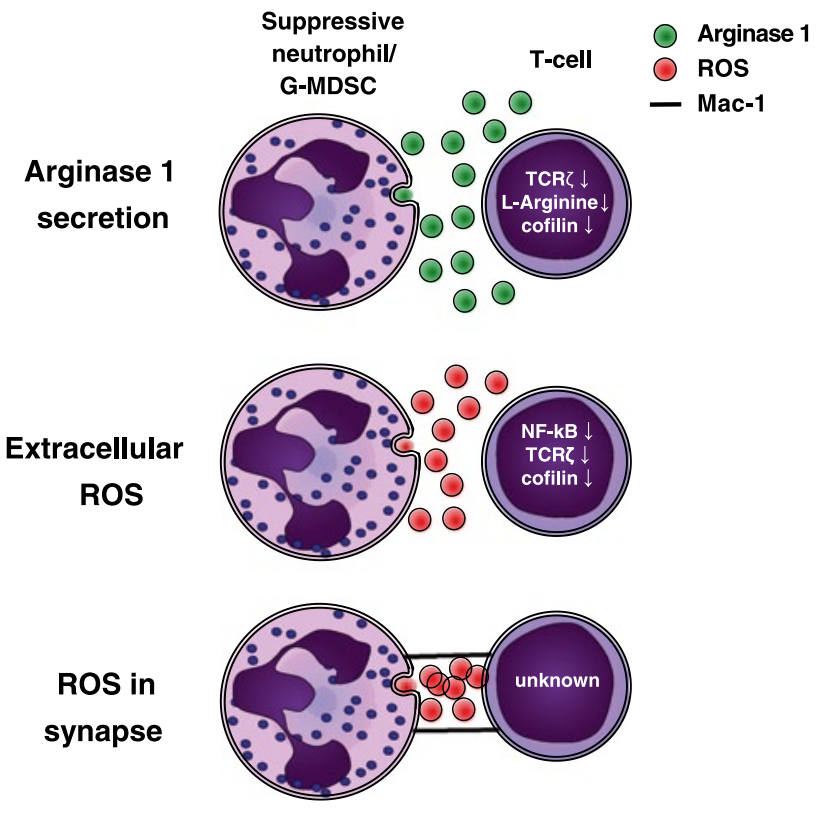

Fig. 3 Mechanisms of suppression by G-MDSCs and suppressive neutrophils. Suppression can be mediated by extracellular arginase, extracellular ROS, or ROS in an immunological synapse. Al these mechanisms result in reduced $\mathrm{T}$ cell proliferation, via decreases in extracellular L-arginine, cofilin, TCR $\zeta$ expression, NF-кB activation, or unknown mechanisms

Production of anti-inflammatory cytokines such as IL-10 by neutrophils has been proposed $[60,66]$. However, this was only observed in murine neutrophils [67] and will, therefore, not be discussed in this review.

Recently, studies have shown that, in addition to limiting $\mathrm{T}$ cell responses, G-MDSCs limit NK-cell responses and activation to vaccinia virus [68]. This was dependent on $\mathrm{H}_{2} \mathrm{O}_{2}$ production by G-MDSCs. Other studies have shown reduced NK-cell responses by G-MDSCs in pregnancy, cancer, and in the tumor environment; however, no mechanism of suppression was reported [69-71].

The role of arginase in T cell suppression by MDSCs

Arginase-1 (ARG1) was shown to be important in the suppression of immune responses by MDSCs in various murine models [72]. ARG1 metabolizes L-arginine into L-ornithine and urea. This depletes L-arginine from the micro-environment. The amino acid L-arginine has multiple roles such as its importance in wound healing [73]. In addition, it is the only endogenous substrate for the production of nitric oxide (NO) by inducible nitric oxide synthase (iNOS) [74]. L-arginine is necessary for $\mathrm{T}$ cell proliferation, as, in the absence of $\mathrm{L}$-arginine, the cell cycle of proliferating $\mathrm{T}$ cells arrests in the G0-G1 phase. [65].

Several mechanisms have been described to explain this L-arginine depletion mediated inhibition of proliferation. 
$\mathrm{L}$-arginine influences the expression of the T cell receptor $\zeta$ chain (TCR $\zeta$, CD247) [75], and ARG-1 has been shown to downregulate TCR $\zeta$ expression and $\mathrm{T}$ cell activation at the level of TCR expression [76, 77]. The TCR/CD3 expression is regulated by continuous internalization and recycling of receptors. The level of surface expression of the receptor regulates the ability of a $\mathrm{T}$ cell to become activated. The rate of synthesis of the TCR $\zeta$-chain is rate limiting to that of the other TCR/CD3 chains. Therefore, this chain is critically important in the regulation of TCR/CD3 internalization and recycling as it stabilizes the TCR/CD3 complex on the cell membrane. [78]. A second mechanism by which a depletion of $\mathrm{L}$-arginine results in $\mathrm{T}$ cell suppression has recently been described. Feldemeyer et al. show that dephosphorylation of cofilin is decreased by depletion of L-arginine. Cofilin is a protein necessary for the remodeling of F-actin [79], which is essential for the formation of an immunological synapse and $\mathrm{T}$ cell proliferation [80].

ARG1 is widely expressed in murine myeloid cells and macrophages. However, in humans, it has only convincingly been shown in neutrophils [34, 81]. Neutrophil ARG1 is synthesized in their myelocyte and metamyelocyte stages and is located in the gelatinase containing granules of mature neutrophils [53, 81]. It is implicated in the host defense against fungi [81]. Activated neutrophils exocytose a form of ARG1 that is catalytically active at $\mathrm{pH} 9.5-10.5$ $[53,82]$. This ARG1 becomes active at a physiological $\mathrm{pH}$ of 7.5 only after cleavage by a co-factor. The co-factor responsible for this cleavage has not been identified, but it has been suggested to be located in azurophil neutrophil granules.

Release of ARG1 by neutrophils requires cellular activation and degranulation of both tertiary (gelatinase) and azurophllic granules. As stated above, human MDSCs have been shown to co-localize with PBMCs when isolated by density separation. Interestingly, fMLF-activated neutrophils from healthy volunteers show similar behavior and co-localize with PBMCs [48]. In patients suffering from severe traumatic injury, the increase of ARG1 activity has also been attributed to activated neutrophils in the PBMC fraction [83]. In addition, increased serum ARG1 correlates with degranulated neutrophils in patients with glioblastoma multiforme [63]. These findings could implicate that G-MDSCs in humans that inhibit $\mathrm{T}$ cell proliferation via an ARG1-mediated mechanism are simply activated granulocytes [49].

As described above, ARG1 expression in myeloid cells of mice and humans is essentially different [84]. Human studies have only correlated the degree and occurrence of ex vivo measured ARG1-mediated T cell suppression to disease progression. Murine studies mostly focused on the association of ex vivo T cells suppression and occurrence of MDSCs in the spleen. The direct contribution of MDSCs to in vivo $\mathrm{T}$ cell suppression in $\mathrm{T}$ cell-mediated diseases has remained largely uninvestigated, although, recently, ARG1 has been shown to limit graft versus host disease (GVHD) in mice. In this study, ARG1-expressing monocytic MDSCs were generated by ex vivo incubation with G-CSF, GMCSF, and IL-13. Adoptive transfer of these ARG1-expressing cells or administration of pegylated-ARG1 limited pathology in this model [72].

\section{Reactive oxygen species}

A hallmark of neutrophils and G-MDSCs is the potential to produce large amounts of reactive oxygen species (ROS). These are generated by the NADPH-oxidase complex in neutrophils. A detailed and schematic description of the generation of ROS is presented by Nathan and Ding [85]. Generation of superoxide anion $\left(\mathrm{O}^{-}\right)$is the first oxygen radical produced. $\mathrm{O}^{-}$can be converted to two substances that have been shown to mediate lymphocyte suppression. Firstly, $\mathrm{O}_{2}^{-}$can react with $\mathrm{NO}$, producing reactive nitrogen species such as peroxynitrite. NO is generated by inducible nitric oxide synthase (iNOS) using L-arginine as substrate, linking the generation of reactive nitrogen species to $\mathrm{L}$-arginine metabolism as described above. Reactive nitrogen species are utilized in some models by monocytic MDSCs, but not by G-MDSCs and neutrophils, and will, therefore, not be discussed in this review [58].

The second substance formed from $\mathrm{O}_{2}^{-}$is $\mathrm{H}_{2} \mathrm{O}_{2}$ (hydrogen peroxide). $\mathrm{H}_{2} \mathrm{O}_{2}$ can be converted by myeloperoxidase to hypochlorous acid $\left(\mathrm{HOCl}^{-}\right) . \mathrm{H}_{2} \mathrm{O}_{2}$ can suppress lymphocyte proliferation through various mechanisms by inducing apoptosis, decreasing $\mathrm{Nf}-\kappa \mathrm{B}$ activation, downregulating TCR $\zeta$, and oxidation of cofilin [86-88].

Cofilin remodeling of F-actin is essential for the T cell effector function. Oxidation of cofilin results in its loss of Ser3 phosphorylation [87]. Dephosphorylated cofilin is unable to mediate actin depolimerization, thus severely disturbing actin dynamics and impairing $\mathrm{T}$ cell activation [80]. Similar to L-arginine depletion, oxidative stress correlates with $\mathrm{TCR} \zeta$ expression, although the exact mechanism is not known. In addition, oxidative stress blocks $\mathrm{Nf}-\kappa \mathrm{B}$ activation leading to impaired $\mathrm{T}$ cell activation [88].

Of note is that regulatory $\mathrm{T}$ cells have been shown to be resistant to oxidative stress [89]. This suggests that regulatory $\mathrm{T}$ cells are less suppressed than other $\mathrm{T}$ cells, thus enhancing the overall suppressive effect of $\mathrm{H}_{2} \mathrm{O}_{2}$ in vivo.

Suppression of $\mathrm{T}$ cell activation and proliferation requires high concentrations of $\mathrm{H}_{2} \mathrm{O}_{2}$ [48, 87], which can be provided by the presence of large numbers of neutrophils at the site of $\mathrm{T}$ cell activation. This might be due to the fact that hydrogen peroxide is unstable and is rapidly converted to $\mathrm{H}_{2} \mathrm{O}$ and $\mathrm{O}_{2}$. Indeed, activated neutrophils or G-MDSCs in 
cancer patients have been shown to inhibit $\mathrm{T}$ cell responses in a $\mathrm{H}_{2} \mathrm{O}_{2}$-dependent manner [48].

The relevance of $\mathrm{H}_{2} \mathrm{O}_{2}$ in the context of G-MDSCs or neutrophil-mediated suppression is difficult to study in animal models. This is mainly due to the diverse biological functions of $\mathrm{H}_{2} \mathrm{O}_{2}$. Besides immune suppression, $\mathrm{H}_{2} \mathrm{O}_{2}$ and its metabolites are involved in bacterial killing [90]. In addition, it functions as a signaling molecule necessary for diverse cellular functions [90] including chemotaxis of immune cells. It has recently been shown that $\mathrm{H}_{2} \mathrm{O}_{2}$ is a potent inducer of chemotaxis of neutrophil-like immune cells in a model of tissue injury in zebrafish [91]. Hydrogen peroxide might, therefore, also indirectly contribute to microbial clearance by attracting immune cells and killing bacteria. These functions of $\mathrm{H}_{2} \mathrm{O}_{2}$ are indispensable in immune processes and, therefore, complicate the interpretation of studies targeting $\mathrm{H}_{2} \mathrm{O}_{2}$ to define its role in immune suppression by G-MDSCs.

Caution must be taken in interpreting ex vivo suppression of T cell proliferation mediated by $\mathrm{H}_{2} \mathrm{O}_{2}$. Manipulation and isolation of neutrophils and G-MDSCs might lead to cell priming and aberrant activation. Also, adhesion to plastic culture dishes might result in cellular activation, degranulation, and reactive oxygen species production resulting in vitro suppression of $\mathrm{T}$ cell responses [92]. Activation of large number neutrophils from healthy volunteers has been shown to suppress $\mathrm{T}$ cell responses ex vivo [87]. Therefore, at least two possibilities exist on how $\mathrm{H}_{2} \mathrm{O}_{2}$ results in immune suppression in vivo. Firstly, a general oxidative environment described by Klemke et al. in which 'normal' activated neutrophils mediate immune suppression. Secondly, as described below, small amounts of $\mathrm{H}_{2} \mathrm{O}_{2}$ can be delivered via the formation of an immunological synapse providing specific and direct suppression of $\mathrm{T}$ cell responses. It would be useful to distinguish between these two mechanisms in future studies concerning G-MDSCs and neutrophil suppression by $\mathrm{H}_{2} \mathrm{O}_{2}$.

Immunological synapse formation, the requirement of cellto-cell contact

The potency of the above-described suppressive mechanisms would be greatly enhanced by cell-to-cell contact and the formation of an immunological synapse. $\mathrm{H}_{2} \mathrm{O}_{2}$ has a short half-life and can be degraded by many endogenous anti-oxidants. Therefore, release into a synapse would potentiate and concentrate local concentrations of $\mathrm{H}_{2} \mathrm{O}_{2}$, $\mathrm{H}_{2} \mathrm{O}_{2}$ is produced in an immunological synapse between $\mathrm{T}$ cells and macrophages and dendritic cells during antigen presentation, and results in decreased lymphocyte activation $[93,94]$. We have recently shown that a subset of neutrophils in human inflammation is capable of directly delivering $\mathrm{H}_{2} \mathrm{O}_{2}$ to the surface of lymphocytes and thereby limiting $\mathrm{T}$ cell activation and proliferation [29]. This contact was dependent on CD11b/CD18, an integrin abundantly expressed by the G-MDSCs in mice. However, in mice, no requirement of cell-to-cell contact suppression by G-MDSCs was found. A very recent study showed that, in patients with gastric cancer, G-MDSCs isolated from the tumor site suppressed $\mathrm{T}$ cells in a contact-dependent manner [95]. Regretfully, no experiments were performed in this latter study to further elucidate the suppressive mechanism.

\section{Distribution of neutrophils and G-MDSCs in lymphoid organs}

In order to modulate the function and proliferation of $\mathrm{T}$ cells, neutrophils or G-MDSCs need to come in contact with or in close proximity to $\mathrm{T}$ cells [96]. $\mathrm{T}$ cell proliferation is normally considered to take place in secondary lymphoid organs such as lymph nodes and the spleen [97]. Recently, $\mathrm{T}$ cell proliferation has also been shown at the site of inflammation [98, 99]. In order to suppress these $\mathrm{T}$ cells, neutrophils will have to be present at these sites. Indeed, many studies show neutrophil homing to sites of T cell proliferation, which will be reviewed in the following section.

Neutrophils in lymphoid organs

Spleen

Neutrophils are known to migrate to the spleen under both homeostatic and pathological conditions [30]. Reinfusion of ex vivo ${ }^{111}$ Indium-labeled neutrophils in healthy controls showed the majority of label in the bone marrow, spleen, and liver $[30,100]$. These studies imply that considerable amounts of neutrophils rapidly home to the spleen after release from the bone marrow. In addition, in mice, about $10 \%$ of reinfused radiolabeled neutrophils migrated towards the spleen, which was not influenced by the maturation status of neutrophils or inflammation [101]. It is important to emphasize that ex vivo manipulation of the cells could have induced subtle changes affecting their homing behavior in vivo [102].

In the spleen, under normal homeostatic conditions, neutrophils reside on the border of the red and white pulp $[103,104]$ and the marginal zone, whereas T cells are found in the white pulp [103]. Consequently, neutrophils should migrate to the white pulp in order to contact the $\mathrm{T}$ cells or vice versa. Neutrophil migration to the white pulp has been shown after intraperitoneal injection of LPS in mice. This was shown to be CD14-dependent [104]. Also, after surgical trauma, neutrophils were found to co-localize with $\mathrm{T}$ cells 
in the spleen [77]. These data demonstrate that neutrophils migrate towards the $\mathrm{T}$ cell zones of the spleen in acute systemic inflammation.

\section{Lymph nodes}

During inflammation, neutrophils are found to migrate to lymph nodes [17, 105-111]. Already in 1987, neutrophil trafficking from lung to draining lymph nodes was described in dogs [1]. In this study, fluorescent microspheres were instilled in the lung of dogs and phagocytosed by neutrophils and macrophages. After $40 \mathrm{~h}$, almost half of the cells in the draining lymph node were neutrophils containing microspheres [105]. Also, in a more physiological model of antigen uptake [111], neutrophils can migrate to draining lymph nodes $[17,106]$. Neutrophils were detected in lymph nodes during infections with Mycobacterium bovis [107], Salmonella [108], and different parasites [109-111]. In some of these models, neutrophils were shown to alter $[17,111]$ or even inhibit the inflammatory response $[106,110]$. The route of migration toward the lymph nodes [107-111] was via the lymphatic system [17, 105-107, 109].

\section{Suppressive neutrophils and G-MDSCs in the spleen}

Almost all studies regarding G-MDSCs in the literature were performed with Ly6G-positive cells isolated from the spleen [31-33]. However, not all of these Ly6G-positive neutrophils in the spleen can suppress T cells [43]. An influx of G-MDSCs into the spleen in mice has been seen both in acute and chronic inflammation such as cancer models [31], parasite infection (Trypanosoma cruzi) [32], and superantigen stimulation (Staphylococcal enterotoxin) [33]. Numbers of G-MDSCs were increased up to 10 -fold 14 days after Trypanosoma cruzi infection [32]. During superantigen stimulation, suppressive neutrophils with highly segmented nuclei were sorted from the spleen [33]; these cells bear a resemblance to the hypersegmented $\mathrm{CD} 16^{\text {bright }} / \mathrm{CD} 62 \mathrm{~L}^{\mathrm{dim}}$ neutrophils that are found in the blood after LPS challenge [29].

Some cancer models increase hematopoiesis, resulting in increased cycling of hematopoietic stem cells and hematopoietic activity in the spleen [112]. Younos et al. showed by in vivo BrdU labeling that in tumor-bearing mice granulocytic proliferation mainly takes place in the spleen, whereas, in control mice, granulocytic cells predominantly proliferate in the bone marrow [113]. The CD3+ cells in this model proliferate less in the tumor-bearing mice, but, unfortunately, they do not show that this immune suppression is a direct effect of the spleen granulocytes. There were also no microscopic pictures of these cells to show their maturation stage [113].
Suppressive neutrophils and G-MDSCs in the lymph nodes

Fewer data are available to show suppressive neutrophils or G-MDSCs in lymph nodes. Sepsis induced an influx of immature myelocytes capable of $\mathrm{T}$ cell suppression in lymph nodes. These cells could be detected 10-14 days after sepsis and remained present in the lymph nodes for at least 12 weeks after sepsis. Cytospins obtained during this study showed a heterogeneous group of cells consisting of both monocytic and granulocytic origin [114].

Vascular endothelial growth factor (VEGF) is able to induce MDSCs in cancer models and is a factor important for immune evasion in several cancer models [115]. Upon infusion of VEGF, myeloid cells, including neutrophils, were massively increased in lymph nodes [116]. Unfortunately, the capacity of these granulocytes to suppress $\mathrm{T}$ cells was not tested. Another indication that MDSCs can migrate to lymph nodes came from a study of Watanabe et al. [117]. They showed that proliferation of $\mathrm{T}$ cells in the lymph nodes of leukocyte-depleted mice was low when injected with spleen cells (containing both T cells and MDSCs) from tumor-bearing mice, compared to proliferation after injection with control mice spleen cells [117]. Proliferation was measured in vitro using cells isolated from lymph nodes. Unfortunately, this model did not discriminate between granulocytic and monocytic MDSCs, so further research is necessary to draw definite conclusions about the presence and importance of suppressive neutrophils in lymph nodes.

\section{$\mathrm{T}$ cell proliferation outside the lymphoid organs}

$\mathrm{T}$ cell proliferation is not restricted to lymphoid organs, because $\mathrm{T}$ cell proliferation was also found, e.g., at sites of viral infection [98, 99, 118-121]. In influenza infection, proliferating $\mathrm{T}$ cells in the lungs contribute substantially to the total number of cytotoxic T-cells in the lung [98, 118]. Also, the persistence and reactivation of influenza-specific CD8+ memory T-cells can take place in mice without secondary lymphoid organs [119]. Similarly, CD8+ T cells proliferate outside the secondary lymphoid organs in a model of $\mathrm{Her}$ pes simplex virus (HSV) reactivation. In this model, infected sensory dorsal root ganglia (DRGs) are transplanted into naïve mice, inducing proliferation in the DRGs of both memory CD8+ T cells from graft [99] and newly recruited CD8+ T cells from the host [120]. Even further, in RSV infected mice, $\mathrm{CD} 4+$ memory $\mathrm{T}$ cells proliferate and differentiate in the lung, but not in the lymph nodes [121].

Taken together, this shows that $\mathrm{T}$ cells can proliferate at sites of viral infection, which is exactly the place where vast amounts of neutrophils are found [122, 123]. Therefore, although it may contribute, neutrophil migration towards the secondary lymphoid organs is not necessary to dampen the immune response. 


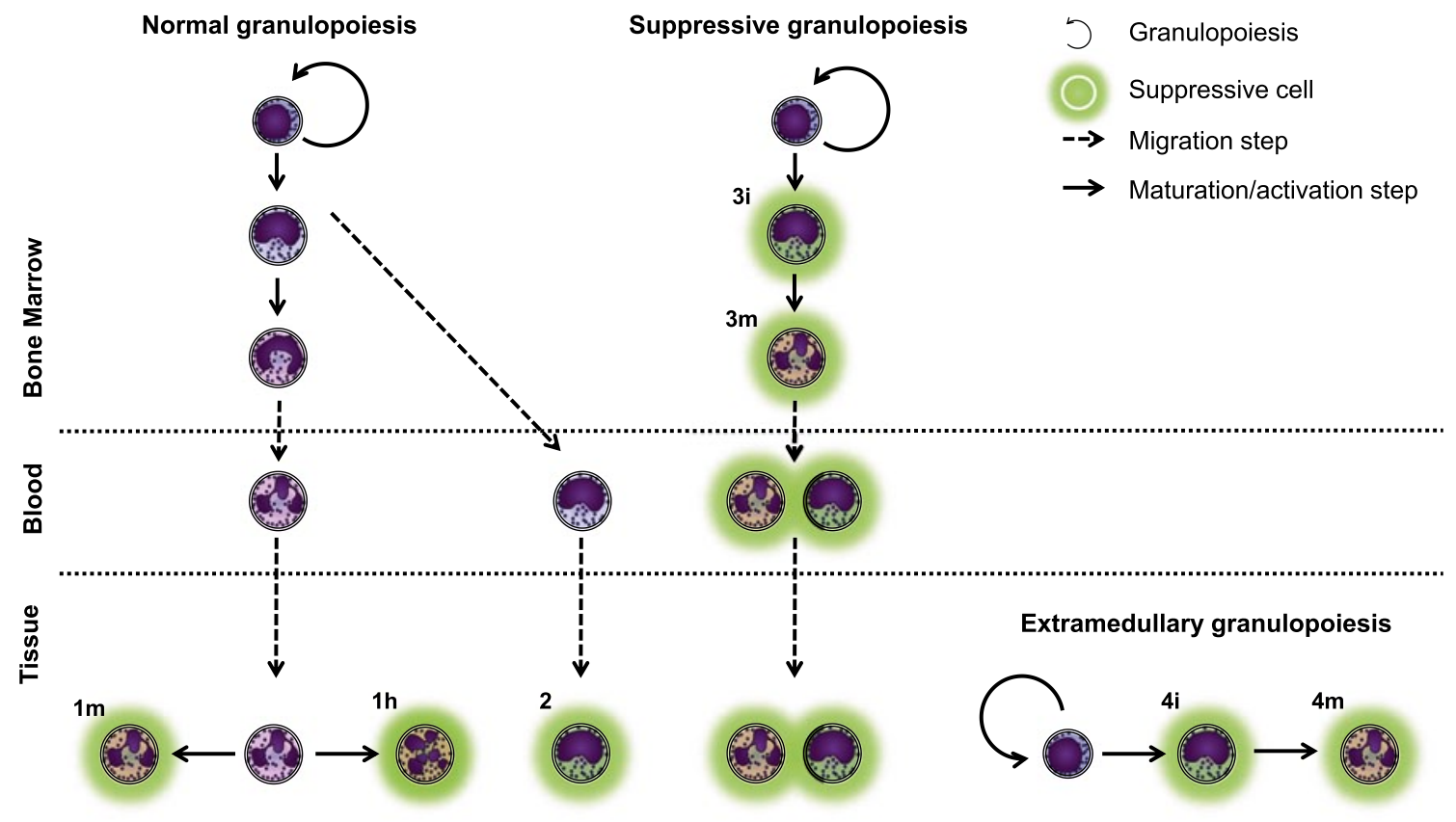

Fig. 4 The origin of G-MDSCs remains unknown. Hypothetically, these calls can arise from mature (1) or immature (2) neutrophils receiving signals to become suppressive. Alternatively, there may be a dedicated granulopoiesis, which only produces suppressive cells.

\section{Origin of G-MDSCs and suppressive neutrophils}

Many papers have shown only a subset of neutrophils to be suppressive. Even further, these suppressive subsets show differences in (flow cytometric) expression patterns and nuclear morphology [28, 29, 44-46]. The difference between normal neutrophils and the different types of suppressive neutrophils may lie in the presence of cytokines or growth factors, (e.g., G-CSF and VEGF) [115, 116, 124] in localization, or in their origin [28]. Few studies have addressed the origin of suppressive phenotypes, and therefore we will briefly discuss four hypotheses regarding the origin(s) of these suppressive cells (Fig. 4):

(a) Suppressive neutrophils might originate from normal, fully maturated cells. These cells acquire a suppressive phenotype under certain (inflammatory) conditions. They can either retain their mature nuclear morphology (Fig. 4, 1m) or become hypersegmented (Fig. 4, 1h).

(b) Cells do not fully mature before exiting from the bone marrow. Progenitors have been found in the peripheral blood under conditions of severe systemic inflammation caused by infection or trauma $[125,126]$. These cells are neutrophil progenitors, which migrate to the tissue and subsequently become suppressive.

(c) An altered or a dedicated suppressive granulopoiesis, underlie the production of G-MDSCs, as suggested
This granulopoiesis can take place either in the bone marrow (3) or extramedullary (4). Additionally, these cells can be immature (i), mature $(m)$ or hypersegmented $(h)$

by the role of G-CSF in several papers [72, 124]. This results in either immature (Fig. 4, 3i) or mature (Fig. 4, $3 \mathrm{~m})$ cells with a suppressive phenotype.

(d) Instead of being produced in the bone marrow, suppressive cells might be produced by extramedullary granulopoiesis. This would result in either immature (Fig. 4, 4i) or mature (Fig. 4, 4m) cells with a suppressive phenotype. For example, Youn et al. [44] described G-MDSCs from tumor-bearing mice were produced in the spleen, whereas neutrophils from healthy mice originated from the bone marrow.

At this moment, it is unclear which of these mechanisms underlie the induction of G-MDSCs and whether multiple mechanisms co-exist. Further research is required to elucidate the origin of different suppressive phenotypes, and whether differences between suppressive phenotypes are caused by differences in their origin or by alternative activation.

\section{A novel hypothesis: G-MDSCs are a phenotype of neutrophils}

Neutrophils do not belong to a single homogenous population of cytotoxic cells with a sole function to eliminate invading microorganisms. In fact, these cells can engage 
with and modulate $\mathrm{T}$ cells and, thereby, shape the adaptive immune system. The lack of consensus regarding nomenclature of these suppressive cells, their heterogeneity, and the lack of suppressive assays in many studies makes it difficult to draw overall conclusions. However, these studies support the hypothesis that multiple types of suppressive neutrophils exist, capable of mediating immune suppression by different mechanisms. Given the recent advances in neutrophil biology, illustrating their plasticity, we hypothesize that G-MDSCs might be a functional heterogenic subset of neutrophils. At this time, it is uncertain how many neutrophil phenotypes exist. It is, however, clear that targeting neutrophils or G-MDSCs as clinical intervention is only effective with knowledge of the different pro- and anti-inflammatory phenotypes, and when origin and kinetics of these cells are adequately elucidated.

Open Access This article is distributed under the terms of the Creative Commons Attribution License which permits any use, distribution, and reproduction in any medium, provided the original author(s) and the source are credited.

\section{References}

1. Nathan C (2006) Neutrophils and immunity: challenges and opportunities. Nat Rev Immunol 6(3):173-182. doi:10.1038/nri1785

2. Patterson MJ, Landolt ML (1979) Cellular reaction to injury in the anthozoan Anthopleura elegantissima. J Invertebr Pathol 33(2):189-196

3. Mydlarz LD, Holthouse SF, Peters EC, Harvell CD (2008) Cellular responses in sea fan corals: granular amoebocytes react to pathogen and climate stressors. PLoS ONE 3(3):e1811. doi:10.1371/journal.pone.0001811

4. Cavaillon JM (2011) The historical milestones in the understanding of leukocyte biology initiated by Elie Metchnikoff. J Leukoc Biol 90(3):413-424. doi:10.1189/jlb.0211094

5. Matsushima H, Geng S, Lu R, Okamoto T, Yao Y, Mayuzumi N, Kotol PF, Chojnacki BJ, Miyazaki T, Gallo RL, Takashima A (2013) Neutrophil differentiation into a unique hybrid population exhibiting dual phenotype and functionality of neutrophils and dendritic cells. Blood. doi:10.1182/blood-2012-07-445189

6. Condliffe AM, Kitchen E, Chilvers ER (1998) Neutrophil priming: pathophysiological consequences and underlying mechanisms. Clin Sci (Lond) 94(5):461-471

7. Coffer PJ, Koenderman L (1997) Granulocyte signal transduction and priming: cause without effect? Immunol Lett 57(1-3):27-31

8. Koenderman L, Yazdanbakhsh M, Roos D, Verhoeven AJ (1989) Dual mechanisms in priming of the chemoattractant-induced respiratory burst in human granulocytes. $\mathrm{A} \mathrm{Ca} 2+-$ dependent and a Ca2 + -independent route. J Immunol 142(2):623-628

9. Hakansson L, Venge P (1994) Priming of eosinophil and neutrophil migratory responses by interleukin 3 and interleukin 5 . Apmis 102(4):308-316

10. Dancey JT, Deubelbeiss KA, Harker LA, Finch CA (1976) Neutrophil kinetics in man. J Clin Invest 58(3):705-715. doi:10.1172/JCI108517

11. Cartwright GE, Athens JW, Wintrobe MM (1964) The kinetics of granulopoiesis in normal Man. Blood 24:780-803

12. Dresch C, Najean Y, Bauchet J (1975) Kinetic studies of 51Cr and DF32P labelled granulocytes. Br J Haematol 29(1):67-80
13. Steinbach KH, Schick P, Trepel F, Raffler H, Dohrmann J, Heilgeist G, Heltzel W, Li K, Past W, van der Woerd-de Lange JA, Theml H, Fliedner TM, Begemann H (1979) Estimation of kinetic parameters of neutrophilic, eosinophilic, and basophilic granulocytes in human blood. Blut 39(1):27-38

14. Pillay J, den Braber I, Vrisekoop N, Kwast LM, de Boer RJ, Borghans JA, Tesselaar K, Koenderman L (2010) In vivo labeling with $2 \mathrm{H}_{2} \mathrm{O}$ reveals a human neutrophil lifespan of 5.4 days. Blood 116(4):625-627. doi:10.1182/blood-2010-01-259028

15. Li KW, Turner SM, Emson CL, Hellerstein MK, Dale DC (2011) Deuterium and neutrophil kinetics. Blood 117(22):6052-6053; author reply 6053-6054. doi:10.1182/blood-2010-12-322271

16. Vincent PC, Chanana AD, Cronkite EP, Joel DD (1974) The intravascular survival of neutrophils labeled in vivo. Blood 43(3):371-377

17. Maletto BA, Ropolo AS, Alignani DO, Liscovsky MV, Ranocchia RP, Moron VG, Pistoresi-Palencia MC (2006) Presence of neutrophil-bearing antigen in lymphoid organs of immune mice. Blood 108(9):3094-3102. doi:10.1182/blood-2006-04-016659

18. Woodfin A, Voisin MB, Beyrau M, Colom B, Caille D, Diapouli FM, Nash GB, Chavakis T, Albelda SM, Rainger GE, Meda P, Imhof BA, Nourshargh S (2011) The junctional adhesion molecule JAM-C regulates polarized transendothelial migration of neutrophils in vivo. Nat Immunol 12(8):761-769. doi:10.1038/ni.2062

19. Buckley CD, Ross EA, McGettrick HM, Osborne CE, Haworth O, Schmutz C, Stone PC, Salmon M, Matharu NM, Vohra RK, Nash GB, Rainger GE (2006) Identification of a phenotypically and functionally distinct population of long-lived neutrophils in a model of reverse endothelial migration. J Leukoc Biol 79(2):303-311. doi:10.1189/jlb.0905496

20. Yoo SK, Huttenlocher A (2011) Spatiotemporal photolabeling of neutrophil trafficking during inflammation in live zebrafish. $\mathbf{J}$ Leukoc Biol 89(5):661-667. doi:10.1189/jlb.1010567

21. Kusmartsev SA, Li Y, Chen SH (2000) Gr-1+ myeloid cells derived from tumor-bearing mice inhibit primary $\mathrm{T}$ cell activation induced through $\mathrm{CD} 3 / \mathrm{CD} 28$ costimulation. J Immunol 165(2):779-785

22. Almand B, Clark JI, Nikitina E, van Beynen J, English NR, Knight SC, Carbone DP, Gabrilovich DI (2001) Increased production of immature myeloid cells in cancer patients: a mechanism of immunosuppression in cancer. J Immunol 166(1):678-689

23. Gabrilovich DI, Velders MP, Sotomayor EM, Kast WM (2001) Mechanism of immune dysfunction in cancer mediated by immature Gr-1+ myeloid cells. J Immunol 166(9):5398-5406

24. Otsuji M, Kimura Y, Aoe T, Okamoto Y, Saito T (1996) Oxidative stress by tumor-derived macrophages suppresses the expression of CD3 zeta chain of T-cell receptor complex and antigen-specific T-cell responses. Proc Natl Acad Sci USA 93(23):13119-13124

25. Peranzoni E, Zilio S, Marigo I, Dolcetti L, Zanovello P, Mandruzzato S, Bronte V (2010) Myeloid-derived suppressor cell heterogeneity and subset definition. Curr Opin Immunol 22(2):238244. doi:10.1016/j.coi.2010.01.021

26. Gabrilovich DI, Bronte V, Chen SH, Colombo MP, Ochoa A, Ostrand-Rosenberg S, Schreiber H (2007) The terminology issue for myeloid-derived suppressor cells. Cancer Res 67(1):425; author reply 426. doi:10.1158/0008-5472.CAN-06-3037

27. Ostanin DV, Kurmaeva E, Furr K, Bao R, Hoffman J, Berney S, Grisham MB (2012) Acquisition of antigen-presenting functions by neutrophils isolated from mice with chronic colitis. J Immunol 188(3):1491-1502. doi:10.4049/jimmunol.1102296

28. Puga I, Cols M, Barra CM, He B, Cassis L, Gentile M, Comerma L, Chorny A, Shan M, Xu W, Magri G, Knowles DM, Tam W, Chiu A, Bussel JB, Serrano S, Lorente JA, Bellosillo B, Lloreta J, Juanpere N, Alameda F, Baro T, de Heredia CD, Toran N, 
Catala A, Torrebadell M, Fortuny C, Cusi V, Carreras C, Diaz GA, Blander JM, Farber CM, Silvestri G, Cunningham-Rundles C, Calvillo M, Dufour C, Notarangelo LD, Lougaris V, Plebani A, Casanova JL, Ganal SC, Diefenbach A, Arostegui JI, Juan M, Yague J, Mahlaoui N, Donadieu J, Chen K, Cerutti A (2012) B cell-helper neutrophils stimulate the diversification and production of immunoglobulin in the marginal zone of the spleen. Nat Immunol 13(2):170-180. doi:10.1038/ni.2194

29. Pillay J, Kamp VM, van Hoffen E, Visser T, Tak T, Lammers JW, Ulfman LH, Leenen LP, Pickkers P, Koenderman L (2012) A subset of neutrophils in human systemic inflammation inhibits $\mathrm{T}$ cell responses through Mac-1. J Clin Invest 122(1):327-336. doi:10.1172/JCI57990

30. Saverymuttu SH, Peters AM, Keshavarzian A, Reavy HJ, Lavender JP (1985) The kinetics of 111indium distribution following injection of 111indium labelled autologous granulocytes in man. Br J Haematol 61(4):675-685

31. Movahedi K, Guilliams M, Van den Bossche J, Van den Bergh R, Gysemans C, Beschin A, De Baetselier P, Van Ginderachter JA (2008) Identification of discrete tumor-induced myeloidderived suppressor cell subpopulations with distinct $\mathrm{T}$ cellsuppressive activity. Blood 111(8):4233-4244. doi:10.1182/ blood-2007-07-099226

32. Goni O, Alcaide P, Fresno M (2002) Immunosuppression during acute Trypanosoma cruzi infection: involvement of Ly6G $(\mathrm{Gr} 1(+)) \mathrm{CD} 11 \mathrm{~b}(+)$ immature myeloid suppressor cells. Int Immunol 14(10):1125-1134

33. Cauley LS, Miller EE, Yen M, Swain SL (2000) Superantigeninduced CD4 $\mathrm{T}$ cell tolerance mediated by myeloid cells and IFN-gamma. J Immunol 165(11):6056-6066

34. Luckner-Minden C, Fischer I, Langhans CD, Schiller M, Kropf P, Muller I, Hohlfeld JM, Ho AD, Munder M (2010) Human eosinophil granulocytes do not express the enzyme arginase. $\mathrm{J}$ Leukoc Biol 87(6):1125-1132. doi:10.1189/jlb.1109741

35. Dumitru CA, Moses K, Trellakis S, Lang S, Brandau S (2012) Neutrophils and granulocytic myeloid-derived suppressor cells: immunophenotyping, cell biology and clinical relevance in human oncology. Cancer Immunol Immunother 61(8):11551167. doi:10.1007/s00262-012-1294-5

36. Schudel L (1965) Leitfaden der Blutmorphologie, 11 edn. Thieme, Stuttgart

37. Daley JM, Thomay AA, Connolly MD, Reichner JS, Albina JE (2008) Use of Ly6G-specific monoclonal antibody to deplete neutrophils in mice. J Leukoc Biol 83(1):64-70. doi:10.1189/ jlb.0407247

38. Elghetany MT (2002) Surface antigen changes during normal neutrophilic development: a critical review. Blood Cells Mol Dis 28(2):260-274

39. Hernandez-Caselles T, Martinez-Esparza M, Perez-Oliva AB, Quintanilla-Cecconi AM, Garcia-Alonso A, Alvarez-Lopez DM, Garcia-Penarrubia P (2006) A study of CD33 (SIGLEC-3) antigen expression and function on activated human $\mathrm{T}$ and NK cells: two isoforms of CD33 are generated by alternative splicing. J Leukoc Biol 79(1):46-58. doi:10.1189/jlb.0205096

40. Griffin JD, Linch D, Sabbath K, Larcom P, Schlossman SF (1984) A monoclonal antibody reactive with normal and leukemic human myeloid progenitor cells. Leuk Res 8(4):521-534

41. Spitalnik PF, Spitalnik SL, Danley JM, Lopez AF, Vadas MA, Civin CI, Ginsburg V (1989) Carbohydrate-specific monoclonal antibodies bind to human granulocytes and stimulate antibody-dependent cellular cytotoxicity. Arch Biochem Biophys 271(1):168-176

42. Ruiz-Cabello F, Lopez Nevot MA, Garrido A, Garrido F (1987) A study of GRM1 monoclonal antibody that reacts with natural killer cells and granulocytes. Nat Immun Cell Growth Regul 6(2):99-108
43. Greifenberg V, Ribechini E, Rossner S, Lutz MB (2009) Myeloid-derived suppressor cell activation by combined LPS and IFN-gamma treatment impairs DC development. Eur J Immunol 39(10):2865-2876. doi:10.1002/eji.200939486

44. Youn JI, Collazo M, Shalova IN, Biswas SK, Gabrilovich DI (2012) Characterization of the nature of granulocytic myeloidderived suppressor cells in tumor-bearing mice. J Leukoc Biol 91(1):167-181. doi:10.1189/jlb.0311177

45. Liu CY, Wang YM, Wang CL, Feng PH, Ko HW, Liu YH, Wu YC, Chu Y, Chung FT, Kuo CH, Lee KY, Lin SM, Lin HC, Wang CH, Yu CT, Kuo HP (2010) Population alterations of L-arginase- and inducible nitric oxide synthase-expressed CD11b+/ CD14(-)/CD15+/CD33+ myeloid-derived suppressor cells and CD8+ T lymphocytes in patients with advanced-stage nonsmall cell lung cancer. J Cancer Res Clin Oncol 136(1):35-45. doi:10.1007/s00432-009-0634-0

46. Mandruzzato S, Solito S, Falisi E, Francescato S, Chiarion-Sileni V, Mocellin S, Zanon A, Rossi CR, Nitti D, Bronte V, Zanovello P (2009) IL4Ralpha + myeloid-derived suppressor cell expansion in cancer patients. J Immunol 182(10):6562-6568. doi:10.4 049/jimmunol.0803831

47. Boyum A (1968) Isolation of mononuclear cells and granulocytes from human blood. Isolation of monuclear cells by one centrifugation, and of granulocytes by combining centrifugation and sedimentation at $1 \mathrm{~g}$. Scand J Clin Lab Invest Suppl 97:77-89

48. Schmielau J, Finn OJ (2001) Activated granulocytes and granulocyte-derived hydrogen peroxide are the underlying mechanism of suppression of t-cell function in advanced cancer patients. Cancer Res 61(12):4756-4760

49. Rodriguez PC, Ernstoff MS, Hernandez C, Atkins M, Zabaleta J, Sierra R, Ochoa AC (2009) Arginase I-producing myeloidderived suppressor cells in renal cell carcinoma are a subpopulation of activated granulocytes. Cancer Res 69(4):1553-1560. doi:10.1158/0008-5472.CAN-08-1921

50. Poschke I, Kiessling R (2012) On the armament and appearances of human myeloid-derived suppressor cells. Clin Immunol 144(3):250-268. doi:10.1016/j.clim.2012.06.003

51. Fridlender ZG, Sun J, Mishalian I, Singhal S, Cheng G, Kapoor V, Horng W, Fridlender G, Bayuh R, Worthen GS, Albelda SM (2012) Transcriptomic analysis comparing tumor-associated neutrophils with granulocytic myeloid-derived suppressor cells and normal neutrophils. PLoS ONE 7(2):e31524. doi:10.1371/ journal.pone.0031524

52. Boxio R, Bossenmeyer-Pourie C, Steinckwich N, Dournon C, Nusse O (2004) Mouse bone marrow contains large numbers of functionally competent neutrophils. J Leukoc Biol 75(4):604611. doi: $10.1189 / \mathrm{jlb} .0703340$

53. Jacobsen LC, Theilgaard-Monch K, Christensen EI, Borregaard $\mathrm{N}$ (2007) Arginase 1 is expressed in myelocytes/metamyelocytes and localized in gelatinase granules of human neutrophils. Blood 109(7):3084-3087. doi:10.1182/blood-2006-06-032599

54. Borregaard N, Theilgaard-Monch K, Sorensen OE, Cowland JB (2001) Regulation of human neutrophil granule protein expression. Curr Opin Hematol 8(1):23-27

55. Goulart MR, Pluhar GE, Ohlfest JR (2012) Identification of myeloid derived suppressor cells in dogs with naturally occurring cancer. PLoS ONE 7(3):e33274. doi:10.1371/journal.pone.0033274

56. Zea AH, Rodriguez PC, Atkins MB, Hernandez C, Signoretti S, Zabaleta J, McDermott D, Quiceno D, Youmans A, O'Neill A, Mier J, Ochoa AC (2005) Arginase-producing myeloid suppressor cells in renal cell carcinoma patients: a mechanism of tumor evasion. Cancer Res 65(8):3044-3048. doi:10.1158/0008-5472. CAN-04-4505

57. Liu Y, Peng SY, Wang L, Wang WJ (2009) Effects of extracts of cheezheng pain relieving plaster on nitric oxide and iNOS 
expression in macrophages induced by lipopolysaccharides. Yao Xue Xue Bao 44(8):863-867

58. Gabrilovich DI, Nagaraj S (2009) Myeloid-derived suppressor cells as regulators of the immune system. Nat Rev Immunol 9(3):162-174. doi: $10.1038 /$ nri2506

59. Fliedner TM, Cronkite EP, Killmann SA, Bond VP (1964) Granulocytopoiesis. Ii. Emergence and pattern of labeling of neutrophilic granulocytes in humans. Blood 24:683-700

60. Noel G, Wang Q, Schwemberger S, Hanson C, Giacalone N, Haar L, Ogle CK (2011) Neutrophils, not monocyte/macrophages, are the major splenic source of postburn IL-10. Shock 36(2):149-155. doi:10.1097/SHK.0b013e3182205cbc

61. Porembka MR, Mitchem JB, Belt BA, Hsieh CS, Lee HM, Herndon J, Gillanders WE, Linehan DC, Goedegebuure P (2012) Pancreatic adenocarcinoma induces bone marrow mobilization of myeloid-derived suppressor cells which promote primary tumor growth. Cancer Immunol Immunother 61(9):1373-1385. doi:10.1007/s00262-011-1178-0

62. Srivastava MK, Bosch JJ, Thompson JA, Ksander BR, Edelman MJ, Ostrand-Rosenberg S (2008) Lung cancer patients' $\mathrm{CD} 4(+) \mathrm{T}$ cells are activated in vitro by MHC II cell-based vaccines despite the presence of myeloid-derived suppressor cells. Cancer Immunol Immunother 57(10):1493-1504. doi:10.1007/ s00262-008-0490-9

63. Sippel TR, White J, Nag K, Tsvankin V, Klaassen M, Kleinschmidt-DeMasters BK, Waziri A (2011) Neutrophil degranulation and immunosuppression in patients with GBM: restoration of cellular immune function by targeting arginase I. Clin Cancer Res 17(22):6992-7002. doi:10.1158/1078-0432.CCR-11-1107

64. Brandau S, Trellakis S, Bruderek K, Schmaltz D, Steller G, Elian M, Suttmann H, Schenck M, Welling J, Zabel P, Lang S (2011) Myeloid-derived suppressor cells in the peripheral blood of cancer patients contain a subset of immature neutrophils with impaired migratory properties. J Leukoc Biol 89(2):311-317. doi:10.1189/jlb.0310162

65. Rodriguez PC, Quiceno DG, Ochoa AC (2007) L-arginine availability regulates T-lymphocyte cell-cycle progression. Blood 109(4):1568-1573. doi:10.1182/blood-2006-06-031856

66. De Santo C, Arscott R, Booth S, Karydis I, Jones M, Asher R, Salio M, Middleton M, Cerundolo V (2010) Invariant NKT cells modulate the suppressive activity of IL-10-secreting neutrophils differentiated with serum amyloid A. Nat Immunol 11(11):1039-1046. doi:10.1038/ni.1942

67. Davey MS, Tamassia N, Rossato M, Bazzoni F, Calzetti F, Bruderek K, Sironi M, Zimmer L, Bottazzi B, Mantovani A, Brandau S, Moser B, Eberl M, Cassatella MA (2011) Failure to detect production of IL-10 by activated human neutrophils. Nat Immunol 12(11):1017-1018; author reply 1018-1020. doi:10.1038/ni.2111

68. Fortin C, Huang X, Yang Y (2012) NK cell response to vaccinia virus is regulated by myeloid-derived suppressor cells. J Immunol 189(4):1843-1849. doi:10.4049/jimmunol.1200584

69. Sceneay J, Chow MT, Chen A, Halse HM, Wong CS, Andrews DM, Sloan EK, Parker BS, Bowtell DD, Smyth MJ, Moller A (2012) Primary tumor hypoxia recruits CD11b+/Ly6Cmed/Ly6G+ immune suppressor cells and compromises NK cell cytotoxicity in the premetastatic niche. Cancer Res 72(16):3906-3911. doi:10.1158/0008-5472.CAN-11-3873

70. Mauti LA, Le Bitoux MA, Baumer K, Stehle JC, Golshayan D, Provero P, Stamenkovic I (2011) Myeloid-derived suppressor cells are implicated in regulating permissiveness for tumor metastasis during mouse gestation. J Clin Invest 121(7):27942807. doi:10.1172/JCI41936

71. Elkabets M, Ribeiro VS, Dinarello CA, Ostrand-Rosenberg S, Di Santo JP, Apte RN, Vosshenrich CA (2010) IL-1beta regulates a novel myeloid-derived suppressor cell subset that impairs
NK cell development and function. Eur J Immunol 40(12):33473357. doi:10.1002/eji.201041037

72. Highfill SL, Rodriguez PC, Zhou Q, Goetz CA, Koehn BH, Veenstra R, Taylor PA, Panoskaltsis-Mortari A, Serody JS, Munn DH, Tolar J, Ochoa AC, Blazar BR (2010) Bone marrow myeloid-derived suppressor cells (MDSCs) inhibit graft-versus-host disease (GVHD) via an arginase-1-dependent mechanism that is up-regulated by interleukin-13. Blood 116(25):5738-5747. doi:10.1182/blood-2010-06-287839

73. Wittmann F, Prix N, Mayr S, Angele P, Wichmann MW, van den Engel NK, Hernandez-Richter T, Chaudry IH, Jauch KW, Angele MK (2005) L-arginine improves wound healing after trauma-hemorrhage by increasing collagen synthesis. J Trauma 59(1):162-168

74. Morris SM Jr (2010) Arginine: master and commander in innate immune responses. Sci Signal 3 (135):pe27. doi: 10.1126/scisignal.3135pe27

75. Rodriguez PC, Zea AH, Culotta KS, Zabaleta J, Ochoa JB, Ochoa AC (2002) Regulation of T cell receptor CD3zeta chain expression by L-arginine. J Biol Chem 277(24):21123-21129. doi:10.1074/jbc.M110675200

76. Yachimovich-Cohen N, Even-Ram S, Shufaro Y, Rachmilewitz J, Reubinoff B (2010) Human embryonic stem cells suppress T cell responses via arginase I-dependent mechanism. J Immunol 184(3):1300-1308. doi:10.4049/jimmunol.0804261

77. Makarenkova VP, Bansal V, Matta BM, Perez LA, Ochoa JB (2006) CD11b+/Gr-1+ myeloid suppressor cells cause T cell dysfunction after traumatic stress. J Immunol 176(4):2085-2094

78. D'Oro U, Munitic I, Chacko G, Karpova T, McNally J, Ashwell JD (2002) Regulation of constitutive TCR internalization by the zeta-chain. J Immunol 169(11):6269-6278

79. Feldmeyer N, Wabnitz G, Leicht S, Luckner-Minden C, Schiller M, Franz T, Conradi R, Kropf P, Muller I, Ho AD, Samstag Y, Munder M (2012) Arginine deficiency leads to impaired cofilin dephosphorylation in activated human T lymphocytes. Int Immunol 24(5):303-313. doi:10.1093/intimm/dxs004

80. Burkhardt JK, Carrizosa E, Shaffer MH (2008) The actin cytoskeleton in T cell activation. Annu Rev Immunol 26:233259. doi:10.1146/annurev.immunol.26.021607.090347

81. Munder M, Mollinedo F, Calafat J, Canchado J, Gil-Lamaignere C, Fuentes JM, Luckner C, Doschko G, Soler G, Eichmann K, Muller FM, Ho AD, Goerner M, Modolell M (2005) Arginase I is constitutively expressed in human granulocytes and participates in fungicidal activity. Blood 105(6):2549-2556. doi:10.1182/ blood-2004-07-2521

82. Rotondo R, Bertolotto M, Barisione G, Astigiano S, Mandruzzato S, Ottonello L, Dallegri F, Bronte V, Ferrini S, Barbieri O (2011) Exocytosis of azurophil and arginase 1-containing granules by activated polymorphonuclear neutrophils is required to inhibit T lymphocyte proliferation. J Leukoc Biol 89(5):721727. doi:10.1189/jlb.1109737

83. Bryk JA, Popovic PJ, Zenati MS, Munera V, Pribis JP, Ochoa JB (2010) Nature of myeloid cells expressing arginase 1 in peripheral blood after trauma. J Trauma 68(4):843-852. doi:10.1097/TA.0b013e3181b026e4

84. Ochoa AC, Zea AH, Hernandez C, Rodriguez PC (2007) Arginase, prostaglandins, and myeloid-derived suppressor cells in renal cell carcinoma. Clin Cancer Res 13(2 Pt 2):721s-726s. doi:10.1158/1078-0432.CCR-06-2197

85. Nathan C, Ding A (2010) SnapShot: reactive oxygen intermediates (ROI). Cell 140(6):951-951 e952. doi:10.1016/j. cell.2010.03.008

86. Gelderman KA, Hultqvist M, Holmberg J, Olofsson P, Holmdahl R (2006) T cell surface redox levels determine $T$ cell reactivity and arthritis susceptibility. Proc Natl Acad Sci USA 103(34):12831-12836 
87. Klemke M, Wabnitz GH, Funke F, Funk B, Kirchgessner H, Samstag Y (2008) Oxidation of cofilin mediates T cell hyporesponsiveness under oxidative stress conditions. Immunity 29(3):404-413. doi:10.1016/j.immuni.2008.06.016

88. Malmberg KJ, Arulampalam V, Ichihara F, Petersson M, Seki K, Andersson T, Lenkei R, Masucci G, Pettersson S, Kiessling R (2001) Inhibition of activated/memory $(\mathrm{CD} 45 \mathrm{RO}(+)) \mathrm{T}$ cells by oxidative stress associated with block of NF-kappaB activation. J Immunol 167(5):2595-2601

89. Mougiakakos D, Johansson CC, Kiessling R (2009) Naturally occurring regulatory $\mathrm{T}$ cells show reduced sensitivity toward oxidative stress-induced cell death. Blood 113(15):3542-3545. doi:10.1182/blood-2008-09-181040

90. Wittmann C, Chockley P, Singh SK, Pase L, Lieschke GJ, Grabher C (2012) Hydrogen peroxide in inflammation: messenger, guide, and assassin. Adv Hematol 2012:541471. doi:10.1155/2012/541471

91. Niethammer P, Grabher C, Look AT, Mitchison TJ (2009) A tissue-scale gradient of hydrogen peroxide mediates rapid wound detection in zebrafish. Nature 459(7249):996-999. doi:10.1038/ nature 08119

92. Ginis I, Tauber AI (1990) Activation mechanisms of adherent human neutrophils. Blood 76(6):1233-1239

93. Gelderman KA, Hultqvist M, Pizzolla A, Zhao M, Nandakumar KS, Mattsson R, Holmdahl R (2007) Macrophages suppress T cell responses and arthritis development in mice by producing reactive oxygen species. J Clin Investig 117(10):3020-3028

94. Varga G, Balkow S, Wild MK, Stadtbaeumer A, Krummen M, Rothoeft T, Higuchi T, Beissert S, Wethmar K, ScharffetterKochanek K, Vestweber D, Grabbe S (2007) Active MAC-1 (CD11b/CD18) on DCs inhibits full T-cell activation. Blood 109(2):661-669

95. Zhuang Y, Peng LS, Zhao YL, Shi Y, Mao XH, Chen W, Pang KC, Liu XF, Liu T, Zhang JY, Zeng H, Liu KY, Guo G, Tong WD, Tang B, Li N, Yu S, Luo P, Zhang WJ, Lu DS, Yu PW, Zou QM (2012) CD8(+) T cells that produce interleukin-17 regulate myeloid-derived suppressor cells and are associated with survival time of patients with gastric cancer. Gastroenterology. doi:10.1053/j.gastro.2012.06.010

96. Haverkamp JM, Crist SA, Elzey BD, Cimen C, Ratliff TL (2011) In vivo suppressive function of myeloid-derived suppressor cells is limited to the inflammatory site. Eur J Immunol 41(3):749759. doi:10.1002/eji.201041069

97. von Andrian UH, Mackay CR (2000) T-cell function and migration. Two sides of the same coin. N Engl J Med 343(14):10201034. doi:10.1056/NEJM200010053431407

98. Lawrence CW, Ream RM, Braciale TJ (2005) Frequency, specificity, and sites of expansion of CD8 + T cells during primary pulmonary influenza virus infection. J Immunol 174(9):5332-5340

99. Wakim LM, Waithman J, van Rooijen N, Heath WR, Carbone FR (2008) Dendritic cell-induced memory T cell activation in nonlymphoid tissues. Science 319(5860):198-202. doi:10.1126/ science. 1151869

100. Szczepura KR, Ruparelia P, Solanki CK, Balan K, Newbold P, Summers C, Chilvers ER, Peters AM (2011) Measuring wholebody neutrophil redistribution using a dedicated whole-body counter and ultra-low doses of 111Indium. Eur J Clin Invest 41(1):77-83. doi:10.1111/j.1365-2362.2010.02382.x

101. Suratt BT, Young SK, Lieber J, Nick JA, Henson PM, Worthen GS (2001) Neutrophil maturation and activation determine anatomic site of clearance from circulation. Am J Physiol Lung Cell Mol Physiol 281(4):L913-L921

102. Summers C, White JF, Mackenzie IM, Solanki C, Peters AM, Chilvers ER (2009) Measurement of neutrophil pulmonary transit time in humans [abstract]. Am J Respir Crit Care Med 179:A1333
103. Nolte MA, Hoen EN, van Stijn A, Kraal G, Mebius RE (2000) Isolation of the intact white pulp. Quantitative and qualitative analysis of the cellular composition of the splenic compartments. Eur J Immunol 30(2):626-634. doi:10.1002/15214141(200002)30:2<626::AID-IMMU626>3.0.CO;2-H

104. Kesteman N, Vansanten G, Pajak B, Goyert SM, Moser M (2008) Injection of lipopolysaccharide induces the migration of splenic neutrophils to the T cell area of the white pulp: role of CD14 and CXC chemokines. J Leukoc Biol 83(3):640-647. doi $: 10.1189 / \mathrm{jlb} .0807578$

105. Harmsen AG, Mason MJ, Muggenburg BA, Gillett NA, Jarpe MA, Bice DE (1987) Migration of neutrophils from lung to tracheobronchial lymph node. J Leukoc Biol 41(2):95-103

106. Yang CW, Strong BS, Miller MJ, Unanue ER (2010) Neutrophils influence the level of antigen presentation during the immune response to protein antigens in adjuvants. J Immunol 185(5):2927-2934. doi:10.4049/jimmunol.1001289

107. Abadie V, Badell E, Douillard P, Ensergueix D, Leenen PJ, Tanguy M, Fiette L, Saeland S, Gicquel B, Winter N (2005) Neutrophils rapidly migrate via lymphatics after Mycobacterium bovis BCG intradermal vaccination and shuttle live bacilli to the draining lymph nodes. Blood 106(5):1843-1850. doi:10.1182/ blood-2005-03-1281

108. Bonneau M, Epardaud M, Payot F, Niborski V, Thoulouze MI, Bernex F, Charley B, Riffault S, Guilloteau LA, Schwartz-Cornil I (2006) Migratory monocytes and granulocytes are major lymphatic carriers of Salmonella from tissue to draining lymph node. J Leukoc Biol 79(2):268-276. doi:10.1189/jlb.0605288

109. Chtanova T, Schaeffer M, Han SJ, van Dooren GG, Nollmann M, Herzmark P, Chan SW, Satija H, Camfield K, Aaron H, Striepen B, Robey EA (2008) Dynamics of neutrophil migration in lymph nodes during infection. Immunity 29(3):487-496. doi:10.1016/j.immuni.2008.07.012

110. Pesce JT, Liu Z, Hamed H, Alem F, Whitmire J, Lin H, Liu Q, Urban JF Jr, Gause WC (2008) Neutrophils clear bacteria associated with parasitic nematodes augmenting the development of an effective Th2-type response. J Immunol 180(1):464-474

111. Tacchini-Cottier F, Zweifel C, Belkaid Y, Mukankundiye C, Vasei M, Launois P, Milon G, Louis JA (2000) An immunomodulatory function for neutrophils during the induction of a CD4+ Th2 response in BALB/c mice infected with Leishmania major. J Immunol 165(5):2628-2636

112. Balducci L, Hardy C (1983) High proliferation of granulocytemacrophage progenitors in tumor-bearing mice. Cancer Res 43(10):4643-4647

113. Younos IH, Dafferner AJ, Gulen D, Britton HC, Talmadge JE (2012) Tumor regulation of myeloid-derived suppressor cell proliferation and trafficking. Int Immunopharmacol 13(3):245-256. doi:10.1016/j.intimp.2012.05.002

114. Delano MJ, Scumpia PO, Weinstein JS, Coco D, Nagaraj S, Kelly-Scumpia KM, O’Malley KA, Wynn JL, Antonenko S, Al-Quran SZ, Swan R, Chung CS, Atkinson MA, Ramphal R, Gabrilovich DI, Reeves WH, Ayala A, Phillips J, Laface D, Heyworth PG, Clare-Salzler M, Moldawer LL (2007) MyD88dependent expansion of an immature GR-1(+)CD11b(+) population induces $\mathrm{T}$ cell suppression and Th2 polarization in sepsis. J Exp Med 204(6):1463-1474. doi:10.1084/jem.20062602

115. Jayaraman P, Parikh F, Lopez-Rivera E, Hailemichael Y, Clark A, Ma G, Cannan D, Ramacher M, Kato M, Overwijk WW, Chen SH, Umansky VY, Sikora AG (2012) Tumor-expressed inducible nitric oxide synthase controls induction of functional myeloid-derived suppressor cells through modulation of vascular endothelial growth factor release. J Immunol 188(11):53655376. doi:10.4049/jimmunol.1103553

116. Gabrilovich D, Ishida T, Oyama T, Ran S, Kravtsov V, Nadaf S, Carbone DP (1998) Vascular endothelial growth factor inhibits 
the development of dendritic cells and dramatically affects the differentiation of multiple hematopoietic lineages in vivo. Blood 92(11):4150-4166

117. Watanabe S, Deguchi K, Zheng R, Tamai H, Wang LX, Cohen PA, Shu S (2008) Tumor-induced CD11b+ Gr-1+ myeloid cells suppress $\mathrm{T}$ cell sensitization in tumor-draining lymph nodes. $\mathrm{J}$ Immunol 181(5):3291-3300

118. McGill J, Legge KL (2009) Cutting edge: contribution of lungresident $\mathrm{T}$ cell proliferation to the overall magnitude of the antigen-specific CD8 T cell response in the lungs following murine influenza virus infection. J Immunol 183(7):4177-4181. doi:10. 4049/jimmunol.0901109

119. Moyron-Quiroz JE, Rangel-Moreno J, Hartson L, Kusser K, Tighe MP, Klonowski KD, Lefrancois L, Cauley LS, Harmsen AG, Lund FE, Randall TD (2006) Persistence and responsiveness of immunologic memory in the absence of secondary lymphoid organs. Immunity 25(4):643-654. doi:10.1016/j.immuni.2006.08.022

120. Wakim LM, Gebhardt T, Heath WR, Carbone FR (2008) Cutting edge: local recall responses by memory T cells newly recruited to peripheral nonlymphoid tissues. J Immunol 181(9):5837-5841

121. Wissinger EL, Stevens WW, Varga SM, Braciale TJ (2008) Proliferative expansion and acquisition of effector activity by memory CD4+ T cells in the lungs following pulmonary virus infection. J Immunol 180(5):2957-2966
122. Perrone LA, Plowden JK, Garcia-Sastre A, Katz JM, Tumpey TM (2008) H5N1 and 1918 pandemic influenza virus infection results in early and excessive infiltration of macrophages and neutrophils in the lungs of mice. PLoS Pathog 4(8):e1000115. doi:10.1371/journal.ppat.1000115

123. Heidema J, Lukens MV, van Maren WW, van Dijk ME, Otten HG, van Vught AJ, van der Werff DB, van Gestel SJ, Semple MG, Smyth RL, Kimpen JL, van Bleek GM (2007) CD8+ T cell responses in bronchoalveolar lavage fluid and peripheral blood mononuclear cells of infants with severe primary respiratory syncytial virus infections. J Immunol 179(12):8410-8417

124. Waight JD, Hu Q, Miller A, Liu S, Abrams SI (2011) Tumorderived G-CSF facilitates neoplastic growth through a granulocytic myeloid-derived suppressor cell-dependent mechanism. PLoS ONE 6(11):e27690. doi:10.1371/journal.pone.0027690

125. Kroepfl JM, Pekovits K, Stelzer I, Fuchs R, Zelzer S, Hofmann P, Sedlmayr P, Dohr G, Wallner-Liebmann S, Domej W, Mueller W (2012) Exercise increases the frequency of circulating hematopoietic progenitor cells, but reduces hematopoietic colonyforming capacity. Stem Cells Dev. doi:10.1089/scd.2012.0017

126. Gibson PG, Manning PJ, O'Byrne PM, Girgis-Gabardo A, Dolovich J, Denburg JA, Hargreave FE (1991) Allergen-induced asthmatic responses. Relationship between increases in airway responsiveness and increases in circulating eosinophils, basophils, and their progenitors. Am Rev Respir Dis 143(2):331-335 